\title{
Course Design Using Axiomatic Design Theory
}

Ziout, Aiman

IMSE Department

University of Windsor, Windsor, ON, Canada

Ziout@uwindsor.ca

\begin{abstract}
In the recommended process for designing a course, the process starts from identifying the course outcomes. The course outcomes are based on the concepts, skills, values, and attitudes that the course instructor wants students to have once they successfully complete the course. Based on the course outcomes, course content, teaching methods, and learning experiences are determined. This highlights the importance of the accurate and effective selection of course outcomes.

In most cases, course outcomes are determined by the course instructor. The quality of the selected outcomes depends on instructor experience, knowledge and values. This introduces a potential weakness into the process. A systematic method that counts for all interested parties in a specific course will be beneficial to develop the most effective courses. This paper investigates the use of axiomatic design methodology for course design. Axiomatic design is an engineering design method that systematically considers requirements of all interested parties in a specific product, and translates these requirements into physical parameters that fully satisfy the requirements.
\end{abstract}

\section{Introduction}

Axiomatic design theory was established by Nam Suh [1]. It was proved to be effective in handling different types of design problems ranging from pure technical to business, social or engineering systems[1].Though the AD is suitable for solving technical and service related problems, exploring its use in educational problems is a promising and excited field of research. Using engineering design tools for solving educational problems is not a new research field, Nelson et al used quality function deployment (QFD) to develop mechanical engineering program that address the changing needs of local industries [2] Akao et al used

\author{
Baki, Fouzia \\ IMSE Department \\ University of Windsor, \\ Windsor, ON, Canada \\ Fouzia1@uwindsor.ca
}

QFD to identify external interested parties in higher education, QFD was used to identify and improve the needs of all interested parties [3]

This paper demonstrates the use of axiomatic design in selecting appropriate courses learning outcomes. It also shows how these outcomes are used to build the teaching methods, learning experiences, and assessment methods

\section{General Overview of Axiomatic Design}

Axiomatic design theory was developed by Nam Suh, it has two main fundamentals: design domains and design axioms.

- Design Domains: according to Suh [1] the design world consist of four domains:

1- Customer domain: is characterized by the needs or attributes that the customer is looking for in the product.

2- Functional domain: where the customer needs are specified in term of functional requirements (FR).

3- Physical domain: where design parameters (DP) are created to satisfy the functional requirements.

4- Process domain: where process variables are determined to produce the product specified by the design parameter.

It is important to know that the FRs are a minimum set of independent requirements that completely cover the functional needs in a specified product. Each FR should be independent of other FRs.

- Design Axioms:

1- Axiom 1: the independent axiom, maintain the independence of the functional requirements, according to this axiom the design solution must be such that each one of 
functional requirements can be satisfied without affecting the other FRs. This can be achieved by selecting the prober set of design parameters in the physical domain.

2- Axiom 2: the information axiom, minimise the information content of the design. The information content of the design can be quantified in terms of the probability that the design parameter will satisfy the functional requirement.

Axiomatic design theory is a comprehensive design theory, it fits technical, and non technical systems. The top-down decomposition of FRs makes this methodology capable to handle complex and complicated systems.

\subsection{Product Design Using Axiomatic Design Theory}

Axiomatic design theory has been used in designing successful products that highly meet customers' needs and expectations $[4,5,6]$ the $\mathrm{AD}$ theory contributes to the robustness of product design by introducing the satisfaction of each functional requirements without affecting other functional requirements

According to $\mathrm{AD}$ the design process starts with customer domain where customer attributes are identified, for example; the customer attribute for car's door would be [4]

1. Easy to open

2. Does not rattle

3. Provide protection in accidents

4. Able to view outside from

The next step is to translate these customer attributes into functions that the final product is able to deliver, so in case of car's door, the functional requirements would be [4]

1. Easy to open

2. Close securely

3. Durable from impacts

4. Allow visibility

Once the functional requirements are defined, the next step is to define the design parameters, which maps the customer's requirements from functional domain to physical domain through the physical design. According to the $\mathrm{AD}$, the best design is where the number of design parameter equals the number of functional requirements. If number of design parameters is more than number of function requirements, then the design is redundant, if it is the opposite then the design is coupled. In both cases decomposing and zigzagging between functional requirements and design parameters are needed.
The final step in $\mathrm{AD}$ is to determine the process variables that are needed to produce the physical design of the product. In the coming sections, this process will be applied to the course design in higher education. It will be further explained by using occupational health and safety course in undergraduate industrial engineering program.

\section{Course Design}

In the process of designing and planning a new course, the following items have to be considered.

1. Course objectives (learning outcomes).

2. Contents domain of the course.

3. Appropriate teaching methods, including available technology.

4. Learning experiences; as type of assignments, learning activities, group work...

5. Assessment methods

6. Resources; available resources are critical for designing appropriate course. Access to technology, library, field experiences, and educational laboratories affect most components of course design process

Course design process - as any design process- require full implementation of all its components. The absence of perfection of any item may lead to ineffective output of the whole process. Though the importance of each element in the design process is not the same, identifying effective course learning outcomes is the key element in the success of fulfilling the whole teaching process. The following section demonstrates the importance of selecting appropriate and effective course outcomes.

\subsection{Definition and Identification of Course Learning Outcomes}

Learning outcomes are statements that specify what students will know, will be able to do, or will be able to demonstrate when they completed or participated in the course, they are expressed as knowledge, skills, attitudes or values [7]

There are many guidelines and check lists that can be used to identify a course learning outcomes. Almost each university has its own quid lines for identifying the learning outcomes of its offered courses

Marilee [8] defined two major characteristics of learning outcomes:

1-learning out comes have to be meaningful : The stated learning outcomes has to be clear and answer questions like, does the outcome aligned with the program outcomes ? Is it important? Is it detailed and specific? Why do I have to include this outcome? 
Learning outcomes has to be meaningful for both faculty and students, and motivate student's interest in the intended course. It has to be focused on what students learns not on what teacher teaches

2- Learning out comes have to be measurable: The purpose of measuring learning outcomes is to provide evidence that the outcomes was or was not achieved. It is recommended to include in the learning outcomes statements the major criterion for measuring that outcome. Attention has to be paid for language used for stating the learning outcome; a nice-wording statement that cannot be measured has to be avoided. The measurements have to include both low and high order thinking outcomes

\section{Proposed Method for Course Design}

This paper suggests the use of AD for constructing the elements of course design in higher education the proposed method is demonstrated in table 1 .

\section{Example: Design of Occupational Health and Safety Course}

Occupational health and safety course is usually offered under industrial engineering department. The expected students for this course are students from different engineering departments, and usually students at their third year.

This course was the choice of this paper due to the fact that there are many interested parties (customers) in the output of this course. In addition to the traditional customers for any course in higher education, like students and faculty, this course has external customers, like governmental health and safety department, and industrial companies which usually hire the graduates of this course. Having different customers affect the whole design process.

The proposed design methodology is used to design this course. According to this methodology customers attributes have to be considered first, basically it is the start point for the whole design process .Identifying the course's customers and their needs and expectations is the foundation for selecting the course outcomes. Table (1) shows the elements of the whole, design process. It starts with customer attributes, which is translated into functional requirements (course learning out comes).

Table 1: Detailed steps of the proposed method

\begin{tabular}{|c|c|c|}
\hline $\begin{array}{l}\text { Axiomatic Design } \\
\text { Domain }\end{array}$ & Description & Example \\
\hline $\begin{array}{l}\text { Customer domain; } \\
\text { Customer's } \\
\text { Attributes }\end{array}$ & $\begin{array}{l}\text { Needs and expectation } \\
\text { of all interested parties } \\
\text { in a certain course }\end{array}$ & $\begin{array}{l}\text { 1-Students : the course has to help us in performing our } \\
\text { expected job } \\
\text { 2- Faculty : he course has not to consume more time than the } \\
\text { specified } \\
\text { 3- Employment bodies : the course has to touch practiced } \\
\text { issues found in our industry }\end{array}$ \\
\hline $\begin{array}{l}\text { Functional domain; } \\
\text { Functional } \\
\text { requirements }\end{array}$ & $\begin{array}{l}\text { Functions course has to } \\
\text { provide } \\
\text { Learning } \\
\text { outcomes }\end{array}$ & $\begin{array}{l}\text { 1-Apply x-method to solve y-problem } \\
\text { 2- Using well- approved method to design effective course } \\
\text { 3- The course provide a lab where students address practical } \\
\text { Problems found in real life cases }\end{array}$ \\
\hline $\begin{array}{l}\text { Physical domain; } \\
\text { Design } \\
\text { parameters }\end{array}$ & $\begin{array}{l}\text { physical methods used } \\
\text { to actualize the } \\
\text { functional requirements } \\
\text { Like } \\
\text { Teaching methods, } \\
\text { contents and learning } \\
\text { experiences }\end{array}$ & $\begin{array}{l}\text { 1- Number of lectures to explain certain topic } \\
\text { 2-Number of assignments and types of activities } \\
\text { 3- Time and resources required for running lab sessions }\end{array}$ \\
\hline $\begin{array}{l}\text { Process domain; } \\
\text { Process variable }\end{array}$ & $\begin{array}{l}\text { Detailed process } \\
\text { variable }\end{array}$ & $\begin{array}{l}\text { 1- lesson plans } \\
\text { 2-selection and design of specific assignments } \\
\text { 3- Design specific assessment method. }\end{array}$ \\
\hline
\end{tabular}


In the physical domain, teaching methods, learning experiences, and assessment methods are identified. Available resources for both faculty and students correspond to constraints in axiomatic design theory; constraints put limits on physical solution for functional requirements. In this example, available resources put limitations on teaching methods, learning experiences, and assessment methods.

Table 2 : Health and safety course design using AD

\begin{tabular}{|c|c|c|}
\hline Domain & Description & Detailed description. \\
\hline $\begin{array}{l}\text { Customer domain; } \\
\text { Customer's } \\
\text { Attributes }\end{array}$ & $\begin{array}{l}\text { Needs and expectation } \\
\text { of all interested parties } \\
\text { in a certain course }\end{array}$ & $\begin{array}{l}\text { 1. Students: to be able to solve technical and administrative } \\
\text { health and safety problems in workplaces. } \\
\text { 2. Program outcomes: provide students with comprehensive } \\
\text { understanding of industrial health and safety engineering and } \\
\text { management. } \\
\text { 3. Governmental health and safety departments: engineers are } \\
\text { responsible for works, public, and their own safety at } \\
\text { workplaces. }\end{array}$ \\
\hline $\begin{array}{l}\text { Functional domain; } \\
\text { Functional } \\
\text { requirements }\end{array}$ & $\begin{array}{l}\text { Functions course has to } \\
\text { provide } \\
\text { Learning } \\
\text { outcomes }\end{array}$ & $\begin{array}{l}\text { 1.1 Carryout accident investigation. } \\
\text { 1.2 Identify workplace hazards. } \\
\text { 1.3 Develop engineering and administrative solutions for } \\
\text { hazards control. } \\
\text { 2.1 Provide overview of health and safety development. } \\
\text { 2.2 Incorporate safety considerations in engineering design } \\
\text { 3.1 Identify related occupational health and safety acts and } \\
\text { regulations. Those are acting in a specific geographical area. } \\
\text { 3.2Demnstrate ability to comply with governing health and } \\
\text { safety regulations. }\end{array}$ \\
\hline $\begin{array}{l}\text { Physical domain; } \\
\text { Design } \\
\text { parameters }\end{array}$ & $\begin{array}{l}\text { physical methods used } \\
\text { to actualize the } \\
\text { functional requirements } \\
\text { Like } \\
\text { Teaching methods, } \\
\text { contents and learning } \\
\text { experiences }\end{array}$ & $\begin{array}{l}\text { 1.1 Report on investigation of real life accident. } \\
\text { 1.2 Lectures on hazards identification and control. } \\
\text { 1.3 Lab assignments on engineering and administrative } \\
\text { solution for unsafe workplace. } \\
\text { 2.1 Lectures on health and safety development } \\
\text { 2.2 Lectures and lab assignments on engineering design } \\
\text { considering safety. } \\
\text { 3.1 Lectures on health and safety regulations and acts. } \\
\text { 3.2 field visits to regulatory agencies. } \\
\text { 3.3 Lectures and lab assignments on complying with health and } \\
\text { safety regulations. }\end{array}$ \\
\hline $\begin{array}{l}\text { Process domain; } \\
\text { Process variable }\end{array}$ & $\begin{array}{l}\text { Detailed } \\
\text { variable }\end{array}$ & $\begin{array}{l}\text { 1.1 By the midterm a } 10 \text { pages report is due on investigation } \\
\text { of real life accident. } \\
1.250 \% \text { of available lectures will be on hazards identification } \\
\text { and control. } \\
1.350 \% \text { of lab assignments on hazards control in unsafe } \\
\text { workplace. }\end{array}$ \\
\hline
\end{tabular}


Cont. : Table 2 : Health and safety course design using AD

\begin{tabular}{|c|c|c|}
\hline Domain & Description & Detailed description. \\
\hline $\begin{array}{l}\text { Process domain; } \\
\text { Process variable }\end{array}$ & $\begin{array}{ll}\begin{array}{l}\text { Detailed } \\
\text { variable }\end{array} & \text { process } \\
\end{array}$ & 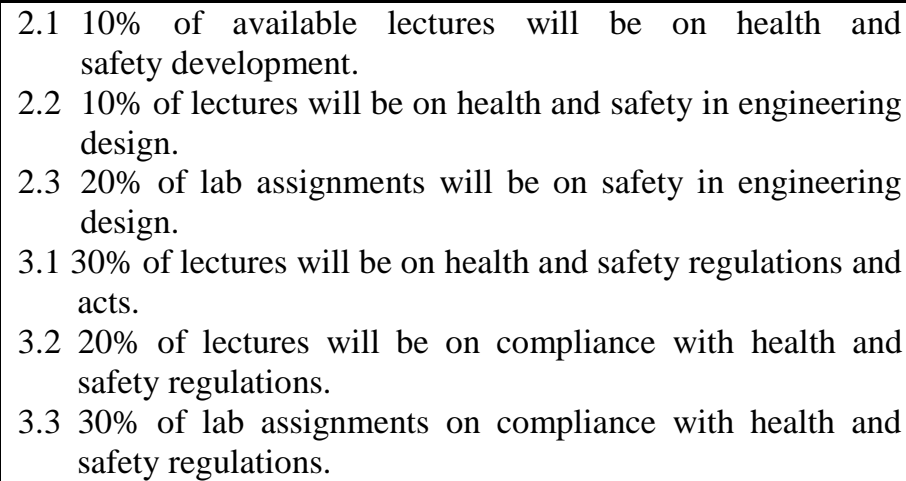 \\
\hline
\end{tabular}

\section{Conclusions}

The work done in this paper concludes with the following:

- Course design is similar to any design process, in the sense of need for design methodology.

- The use of axiomatic design methodology helped in improving the course design process, by initial consideration of needs and expectations of all interested parties (customers) in a specific course.

- Effective course outcomes come from the list of needs and expectations of interested parties.

- The proposed method was found effective in constructive alignment between course outcomes, teaching methods, learning experiences, and assessment methods.

- The proposed methodology is helpful in breaking down the learning outcomes into more detailed sub outcomes.

\section{Future Work}

The proposed method in this paper did not include the whole components and steps in axiomatic design. More work is needed to include the remaining steps in axiomatic design to be included in course design, specifically, the second axiom in axiomatic design.
Implementation of the proposed method in different fields will contribute to the validation and evaluation of the effectiveness of the proposed method.

\section{References}

[1]: Suh N. P., (2001). Axiomatic Design; Advances and Applications. Oxford university press, New York.

[2]: Nilsson Per Bengt Lofgren and Gunnar Erixon (1995) QFD in the development of engineering studies trans actions from the seventh symposium on quality function deployment Novi, Michigan Ann Arbor MI QFD Institute PP 519-529- ISBN 1889477-07-9.

[3]: Yoj Nagai, and Nobuhiro Maki. (1996).QFD concept for improving higher education Proceedings of ASQCS $50^{\text {th }}$ annual quality congress Pp 12 -20.

[4]: Noel, M,(2001),"applying axiomatic design principles to the house of quality" MSc thesis ,industrial engineering department university of Windsor Canada

[5] Kim, T. 1995) implementation of axiomatic design Theory MSc. Thesis, department of mechanical engineering MIT ,Massachusetts USA

[6]: Kumer, V,(1988) "process synthesis for manufacturing micro cellular thermoplastic parts :A case study in axiomatic design ,PhD thesis, MIT Massachusetts, USA 
[7]: Office of student learning and outcomes assessment. (2010) "student learning outcomes 101 university of Rhode Island, Kingston, RI, USA. Retrieved May 14 ${ }^{\text {th }} 2010 . \quad$ www.uri.edu/ assessment.
[8] Marilee, J., (2010) ,writing measurable and meaningful outcomes :viewed at may $14^{\text {th }} 2010$. www.netresults.com 